\title{
An Experimental Study to Assess the Effectiveness of Self-defense Training among Nursing Students, their Knowledge and Practices in Selected Nursing Institute of Mumbai City
}

\author{
Shweta Kshirsagar', Smita Barmase², Komal Jadhav', Priyanka Thoka', Tazeen Shaikh¹, Swarali Sawant', Kiran Shukla1, Akshaya Pookandy', Mayuri Gavandha', \\ Prasad Chavan ${ }^{1}$ \\ ${ }^{1}$ Department of Midwifery and Obstetrical Nursing, K. J. Somaiya College of Nursing, Mumbai, Maharashtra, India, ${ }^{2}$ Department of Child Health Nursing, K. J. Somaiya \\ College of Nursing, Mumbai, Maharashtra, India
}

\section{Abstract}

Background: Self-defense is a risk reduction strategy that may offer assertiveness training and strategies to physically and verbally resist dangerous situations. It provides individuals with confidence, awareness, and diffusion strategies to increase their safety and potentially lessen the severity of attacks.

Aim: The aim of the study was to assess the effectiveness of self-defense training among nursing student's knowledge and practices in selected nursing institute of Mumbai city.

Materials and Methods: A total of 25 subjects (female) were selected from $1^{\text {st }}$ year B.Sc. Nursing of K. J. Somaiya College of Nursing by nonprobability purposive sampling technique. Pre-test knowledge was evaluated before the session of self-defense. $2 \mathrm{~h}$ self-defense training session was given to the study subjects and post-test knowledge was assessed.

Results: Knowledge pre-test and post-test mean score is 5.16 and 6.96, standard deviation (SD) 1.43 and 1.34 , and structural equation modeling (SEM) 0.29 and 0.27, respectively, with $\mathrm{t}=6.00, \mathrm{df}=24$, and standard error of difference $=0.300$, whereas two-tailed $P<0.0001$ which is suggestive of extremely statistically significant results. Practice pre-test and post-test mean score is 3.76 and 12.92 , SD 1.64 and 1.41; SEM 0.33 and 0.28 , respectively, with $\mathrm{t}=22.2863, \mathrm{df}=24$, and standard error of difference $=0.411$, whereas two-tailed $P<0.0001$ which is suggestive of statistically significant results.

Conclusion: Self-defense training is now a day's essential training program for all female students to improve their knowledge and skills to defend herself during any assault.

Keywords: Mumbai, nursing, self-defense training

\section{INTRODUCTION}

Violence against women is a worldwide yet still hidden problem. Freedom from the threat of harassment, battering, and sexual assault is a concept that most of the people have a

\begin{tabular}{|l|}
\hline \multicolumn{1}{|c|}{ Access this article online } \\
\hline Website: http://innovationalpublishers.com/Journal/ijnmi \\
\hline ISSN No: $2656-4656$ \\
DOI: $10.31690 /$ ijnmi/51 \\
\hline
\end{tabular}

hard time imagining because violence is such a deep part of our cultures and our lives. Violence against women is woven into the fabric of society to such an extent that many of the women who are victimized think that they are at faults. Everyday people see images of male violence against women in the news, on TV shows, in the movies, and in our homes and workplaces. It is a fact for women of all ages, races, and classes. ${ }^{[1]}$

Physical violence, stranger abduction, and abuse at the hands of a parent/guardians are the reality for many girls and women. The National Crime Victims Survey often includes victims beginning at age 12 . In addition, the highest rates of rape and sexual

Address for Correspondence:

Mrs. Shweta Kshirsagar, Department of Midwifery and Obstetrical Nursing, K. J. Somaiya College of Nursing, Mumbai, Maharashtra, India.

E-mail: shwetanaik333@gmail.com

This is an open-access journal, and articles are distributed under the terms of the Creative Commons Attribution Noncommercial Share Alike 4.0 License, which allows others to remix, tweak, and build upon the work non-commercially, as long as appropriate credit is given and the new creations are licensed under the identical terms 
assault are found among women aged 12-24 years. ${ }^{[2]}$ Females in their teens and 20s are those most likely to be dating and, therefore, subject to dating violence. For girls, there are adverse consequences that have been linked to early victimization, including increased mental illness, failure in school, use of drugs and alcohol, and teen pregnancy. Violence toward girls is very real and something that needs to be addressed. ${ }^{[3]}$

A 2013 analysis conducted by the WHO with the London School of Hygiene and Tropical Medicine and the South African Medical Research Council, used existing data from over 80 countries, and found that worldwide, 1 in 3 , or $35 \%$ of women experienced physical and sexual violence by an intimate partner or non-partner sexual violence. Globally, as many as $38 \%$ of murders of women are committed by a male intimate partner. Violence can negatively affect women's physical, mental, sexual, and reproductive health and may increase the risk of acquiring HIV in some settings. The prevalence estimates of intimate partner violence range from $24.2 \%$ in high-income countries and $24.6 \%$ in the WHO western pacific region to $37 \%$ in the WHO Eastern Mediterranean region and $37.7 \%$ in the WHO Southeast Asia region. These statistics tell something very important that women are not being equipped to defend themselves against an attacker. The data paints a dark picture and definitely something should be done about it. ${ }^{[4]}$

In health care system, nurses, and other health care providers increasingly deal with verbal abuse, physical assaults, and injury often from the patient or other they are trying to help. Nurses have shift duties and come across various people in day and night such as doctors, relatives, patients, blue-collar workers, and health care workers of opposite gender with age variations. Many times, we hear people are pinpointing or molestating us. In this scenario, role of defense becomes very important. Hence, the present study was aimed assess the effectiveness of self-defense training among nursing student's knowledge and practices in selected nursing institute of Mumbai city.

\section{Materials and Methods}

A total of 25 subjects (female) were selected from $1^{\text {st }}$ year B.Sc. Nursing of K. J. Somaiya College of Nursing by nonprobability purposive sampling technique. Students were excluded if they were studying in higher classes and refused to participate in the study.

\section{Study tool}

The study tool comprised of two sections. Section I contained questions related to sociodemographic variables such age, living status, type of travel and transport, and type of family. Section II contained 10 questionnaires related to self-defense.

\section{Methodology}

A pre-test was taken by giving questionnaire to assess the previous knowledge of the subjects regarding self-defense training and a checklist was used to assess the knowledge regarding self-defense skills. Later, a self-defense training session was taken by SAHAS- an organization and practice of the self-defense techniques was taken and a post-test was given again consisting of the same questionnaire and checklist to assess the effectiveness of self-defense training on knowledge and practice among students.

\section{Statistical analysis}

Data were presented as frequency and percentage. Quantitative variables within the groups were measured using paired $t$-test. $P<0.05$ was considered statistically significant.

\section{RESULTS \\ Sociodemographic characteristics}

Table 1 summarizes the sociodemographic characteristics of the study subjects. About $64 \%$ of students' age was between 18 and 20 years while $36 \%$ students aged below 18 years. About $96 \%$ of the students were unmarried. About $56 \%$ of the students were day scholars while $40 \%$ were residing in hostels. Remaining 4\% were living in their guardians' house. About $48 \%$ students use train as a mode of transport followed by $40 \%$ students who walk to travel. About $64 \%$ students preferred to travel alone. About $72 \%$ of the students belonged to nuclear family. About $8 \%$ students had previous experience of abuse while none of the students reported their ability to protect themselves.

\section{Self-defense session significantly improved the knowledge and practice}

We observed that there was significantly increase in knowledge and practice about self-defense after administration of selfdefense session [Table 2].

We observed that students were also able to increase knowledge about individual questions related to knowledge such as meaning of self-defense, need of self-defense, aim of selfdefense, types of defensive assets, immediate action to selfdefense, the phrase to seek public attention, best way to carry hand bag, children and women safety helpline number, required self-defense technique, and you feel safest when u have [Table 3]. Similarly, each practice related to self-defense such as confidence while implementing self-defense techniques, ability to implement self-defense techniques, ability to tackle attacking situation using self-defense techniques, response to harassing situations, creating public awareness, awareness about the surrounding, and ability to protect herself successfully [Table 4].

\section{Discussion}

Indian society has always revered women. In Hinduism, man and woman represent the two halves of the divine body. There is no question of superiority or inferiority between them. Hindu history is witness to the superwomen such as Gargi, Maitreyi, and Sulabha, whose faculty of reasoning was far superior to that of ordinary mortals. Many female deities 
Saraswati, Durga, Laxmi, Kali, etc., are worshipped across the country. According to the Mahabharat by cherishing, the woman one virtually worships the goddess of prosperity.

On the darker side, the patriarchal system has continued since the time of Rig Veda. Customs and values were made by men to favor men. Women suffer this discrimination in silence.

In our study, students had nearly no knowledge and practice related to self-defense. This is in concordance with study by Lakra at Kavith who reported that nurse students had average knowledge of self-defense. ${ }^{[5]}$ We observed that the training session significantly improved the knowledge and practice of student nurses related to self-defense. It has been reported that self-defense classes not only build confidence but also reduce their risk of exposure to violence. ${ }^{[6]}$

Self-defense could contribute to challenges construct of vulnerable, timid femininity and enable women and girls to develop a confident relationship with their bodies. ${ }^{[7]}$ It has also been adapted to groups considered "vulnerable" - specifically girls and women with disabilities; it is also provision that many survivors take up. In terms of empowerment, self-defense is one of the few interventions that take embodied empowerment as its focus and purpose: Unlike much safety advice which may limit women's freedom, self-defense seeks to expand it.

Several risk factors have been suggested as risk factors for the violence against women such as younger age, poor socioeconomic status, and urban domicile. ${ }^{[8-10]}$ Lakra and

Table 1: Sociodemographic characteristics

\begin{tabular}{|c|c|c|c|}
\hline Demoghraphic characteristic & Category & Frequency (f) & Percentage \\
\hline \multirow{3}{*}{ Age group } & $<18$ years & 9 & 36 \\
\hline & $18-20$ years & 16 & 64 \\
\hline & $>20$ years & 0 & 0 \\
\hline \multirow[t]{2}{*}{ Marital status } & Married & 1 & 4 \\
\hline & Unmarried & 24 & 96 \\
\hline \multirow[t]{4}{*}{ Type of residence } & Hostilities & 10 & 40 \\
\hline & Day scholar & 14 & 56 \\
\hline & Guardians & 1 & 4 \\
\hline & house & & \\
\hline \multirow[t]{4}{*}{ Modes of transport } & By walk & 10 & 40 \\
\hline & Autoricks & 0 & 0 \\
\hline & Bus & 3 & 12 \\
\hline & Train & 12 & 48 \\
\hline \multirow[t]{2}{*}{ Traveling } & Group & 9 & 36 \\
\hline & Individual & 16 & 64 \\
\hline \multirow[t]{2}{*}{ Family } & Nuclear & 18 & 72 \\
\hline & Joint & 7 & 28 \\
\hline \multirow{2}{*}{ Previous experience of any abuse } & Yes & 2 & 8 \\
\hline & No & 23 & 92 \\
\hline \multirow{2}{*}{ Ability to protect/defend themselves } & Yes & 0 & 0 \\
\hline & No & 2 & 100 \\
\hline
\end{tabular}

Table 2: Role of self-defense session on knowledge and practice

\begin{tabular}{|c|c|c|c|c|c|c|}
\hline Variable & Experiment & Mean & SD & SEM & SED & Paired $t$-test value \\
\hline \multirow[t]{2}{*}{ Self-defense knowledge score } & Pre-test & 5.16 & 1.43 & 0.29 & 0.300 & 6.0000 \\
\hline & Post-test & 6.96 & 1.34 & 0.27 & & \\
\hline \multirow[t]{2}{*}{ Self-defense practice score } & Pre-test & 3.76 & 1.64 & 0.33 & 0.411 & 22.2863 \\
\hline & Post-test & 12.92 & 1.41 & 0.28 & & \\
\hline
\end{tabular}

Degree of freedom=24; $P<0.0001$ for knowledge and practice, SD: Standard deviation, SEM: Structural equation modeling

Table 3: Distribution of subjects according to their pre-test and post-test knowledge score

\begin{tabular}{|c|c|c|c|c|c|}
\hline \multirow[t]{3}{*}{ Question No. } & \multirow[t]{3}{*}{ Questionnaire } & \multirow{2}{*}{\multicolumn{2}{|c|}{$\begin{array}{c}\text { Pre-test (T1) } \\
\text { Appropriate answer }\end{array}$}} & \multirow{2}{*}{\multicolumn{2}{|c|}{$\begin{array}{c}\text { Post-test (T2) } \\
\text { Appropriate answer }\end{array}$}} \\
\hline & & & & & \\
\hline & & $\left(f_{1}\right)$ & $(\%)$ & $\left(f_{2}\right)$ & $(\%)$ \\
\hline 1. & Meaning of self-defense & 19 & 76 & 24 & 96 \\
\hline 2. & Need of self-defense & 17 & 68 & 23 & 92 \\
\hline 3. & Aim of self-defense & 12 & 48 & 19 & 76 \\
\hline 4. & Types of defensive assets & 8 & 32 & 21 & 84 \\
\hline 5. & Immediate action to self defense & 5 & 20 & 12 & 48 \\
\hline 6. & The phrase to seek public attention & 13 & 52 & 14 & 56 \\
\hline 7. & Best way to carry hand bag & 4 & 16 & 9 & 36 \\
\hline 8. & Children and women safety helpline number & 13 & 52 & 07 & 28 \\
\hline 9. & Required self-defense technique & 16 & 64 & 22 & 88 \\
\hline 10. & You feel safest when u have & 18 & 72 & 21 & 84 \\
\hline
\end{tabular}


Table 4: Distribution of subjects according to their pre-test and post-test practice response

\begin{tabular}{|c|c|c|c|c|c|}
\hline \multirow[t]{2}{*}{ S. No. } & \multirow[t]{2}{*}{ Questionnaire } & \multicolumn{2}{|c|}{ Pre-test } & \multicolumn{2}{|c|}{ Post-test } \\
\hline & & $\left(f_{1}\right)$ & $(\%)$ & $\left(f_{2}\right)$ & $(\%)$ \\
\hline 1. & Confident while implementing self-defense techniques & 5 & 20 & 22 & 88 \\
\hline 2. & Able to implement self-defense techniques & 3 & 12 & 22 & 88 \\
\hline 3. & Able to tackle attacking situation using self-defense techniques & 1 & 4 & 25 & 100 \\
\hline 4. & Situation no. 1 - if someone grabs you from behind & 2 & 8 & 21 & 84 \\
\hline 5. & Situation no.2 - if someone tries to choke you & 9 & 36 & 22 & 88 \\
\hline 6. & Situation no. 3 - if someone pushes you against a wall & 3 & 12 & 23 & 92 \\
\hline 7. & Creating public awareness & 11 & 44 & 14 & 56 \\
\hline 8. & Aware about the surrounding & 9 & 36 & 24 & 96 \\
\hline 9. & Able to protect herself successfully & 2 & 8 & 21 & 84 \\
\hline
\end{tabular}

Kavith reported that there was no significant association of knowledge scores with selected sociodemographic variables.

\section{Conclusion}

Self-defense is an important technique to instill confidence and made the women have self-ability to deal with the violence.

\section{RefERENCES}

1. Sokoloff NJ, Dupont I. Domestic violence at the intersections of race, class, and gender: Challenges and contributions to understanding violence against marginalized women in diverse communities. Violence Against Women 2005;11:38-64.

2. Bachman R, Saltzman LE. Violence against Women: Estimates from the Redesigned Survey. NCJ-154348. Washington, D.C.: Bureau of Justice Statistics, U.S. Department of Justice; 1995.

3. Sharma I. Violence against women: Where are the solutions? Indian J Psychiatry 2015;57:131-9.

4. World Health Organization. The World Report on Violence and Health. Available from: https://www.apps.who.int/iris/bitstream/ handle/10665/85239/9789241564625_eng.pdf;jsessionid=7B29B1B8FF7 FB51230779DAC15495609? sequence $=1$. [Last accessed on 2019 Sep 04].

5. Lakra LR, Kavith AS. Assess the awareness regarding self defence against public violence among B.Sc. Nursing first year students. Int J Adv Sci Res 2017;2:19-22.

6. Instilling Confidence through Self-Defense. Available from: https:// www.news.miami.edu/stories/2018/11/instilling-confidence-throughself-defense.html. [Last accessed on 2019 Sep 04].

7. The Council of Europe Convention on preventing and combating violence against women and domestic violence, 2011. Available from: https://www.rm.coe.int/CoERMPublicCommonSearchServices/Displ ayDCTMContent?documentId $=090000168046 \mathrm{e} 1 \mathrm{f} 0$. [Last accessed on 2019 Sep 18].

8. Kumar S, Jeyaseelan L, Suresh S, Ahuja RC. Domestic violence and its mental health correlates in Indian women. Br J Psychiatry 2005; 187:62-7.

9. Nambi S. Forensic Psychiatry (Psychiatry and Law) Indian Perspective. Psychosocial and Legal Aspects of Domestic Violence. $1^{\text {st }}$ ed. Chennai: Manushanthi Mental Healthcare Pvt Ltd.; 2011.

10. Babu BV, Kar SK. Domestic violence in eastern India: Factors associated with victimization and perpetration. Public Health 2010;124:136-48

How to cite this article: Kshirsagar S, Barmase S, Jadhav K, Thoka $\mathrm{P}$, Shaikh T, Sawant S, Shukla K, Pookandy A, Gavandha M, Chavan P. An Experimental Study to Assess the Effectiveness of Self-defense Training among Nursing Student's Knowledge and Practices in Selected Nursing Institute of Mumbai City. Int J Nurs Med Invest. 2019;4(3):54-57. 